\title{
Nutritive value of three fodder species at different stages of maturity
}

\author{
AR Kanak ${ }^{1}$, MJ Khan², MR Debi*2, MK Pikar¹, M Aktar ${ }^{3}$ \\ ${ }^{1}$ Department of Livestock Services, Savar, Dhaka; ${ }^{2}$ Department of Animal Nutrition, Bangladesh Agricultural \\ University, Mymensingh-2202; ${ }^{3}$ Department of Animal Breeding Genetics and Animal Nutrition, Sher-e-Bangla \\ Agricultural University, Sher-e-Bangla Nagar, Dhaka, Bangladesh
}

\begin{abstract}
An experiment was conducted to compare the nutritive value of three fodder species: Para (Brachiaria mutica Stapf.), German (Echinochloa crusgalli L.) and Dhal (Hymenachne pseudointerrupta C. Muell) at three different stages of maturity. The grasses were cultivated in 9 plots arranged in completely randomized design having three replications for each fodder. The area of each unit plot was $6 \mathrm{~m} \times 6 \mathrm{~m}$. Number of cuttings were 16,000 /hectare, where plant to plant distance was $16 \mathrm{~cm}$ and row to row distance was $16 \mathrm{~cm}$. Equal amount of organic and chemical fertilizer were applied in all stages of maturity. The fodders were first harvested after $60 \mathrm{~d}$ of planting, second and third harvests were done after successive $60 \mathrm{~d}$ of re-growth. There was highly significant $(p<0.01)$ variation on DM content among the three fodders in the first and third cuttings and significant $(p<0.05)$ difference was observed in the second cutting. There was also significant $(p<0.01)$ effect on Ash content in the first cutting. Significant difference at $1 \%$ and $5 \%$ level of probability was observed in NFE content in the third and second cutting, respectively. Crude fiber (CF) content was only significant $(p<0.05)$ in the third cutting. Among the three grasses German grass showed higher value in the proximate components except EE and CP (non-significant) than other grasses. Para, German and Dhal grasses were differed insignificantly $(p>0.05)$ in terms of IVOMD and ME content in all stages of maturity. The highest values (58.35, 59.97 and $61.92 \%$ ) of IVOMD were found in German grass compared to those of Para and Dhal grasses in all stages of maturity. The highest ME values ( 8.18 and $8.42 \mathrm{MJ} / \mathrm{kg} \mathrm{DM}$ ) were also found in German grass than other grasses in the second and third stages of maturity. From the above findings it may be concluded that among the three fodders, German grass showed the best result in respect of nutritive value.
\end{abstract}

Key words: Fodders, stages of maturity, comparison, nutritive value

Bangladesh Animal Husbandry Association. All rights reserved. Bang. J. Anim. Sci. 2012. 41 (2): 90-95

\section{I ntroduction}

Bangladesh has an area of $1,47,570 \mathrm{sq} . \mathrm{Km}$ with net cropped area of 1.2 million hectares. There is 0.03 million hectares of cultivable land lying fallow and 0.29 million hectare is unavailable for cultivation. About $80 \%$ of the total cultivable land is used for cultivation of cereal crops and only $0.03 \%$ for cultivation of fodder crops and the rest for other crops (BBS 2009). Scarcity of animal feeds and fodder has been identified as a major constraint for the development of livestock in Bangladesh. In Bangladesh, cattle live mostly on straw based ration. So livestock development in Bangladesh is mainly depending upon the improvement of animal nutrition through improved feeding and availability of fodder. In this situation, it is of prime consideration to introduce suitable high yielding varieties of perennial fodder crops to the farmers (Ali et al. 1987). On a straw-based diet, supplementation of small amount of green grass is often recommended for optimization of rumen environment (Preston and Leng, 1987) or even to meet the maintenance requirement of animal (Ranjhan and Singh 1993). Para, German, and Dhal grass are three important fodders suitable for production in the context of Bangladesh climate. The most significant feature of these three fodders is that, they can grow both high and low lands or in water logging condition (Khan et al. 2009). But no research work was undertaken on comparison between these fodders in respect of productivity, nutritive value etc. To meet up the increasing need of green fodder, it is essential to find out some potential fodder germplasm and recommend for extensive cultivation by the farmers for feeding their productive animals. The experiment was conducted to compare the nutritive of above three fodders at different stages of maturity. 


\section{Materials and Methods}

\section{Location of experiment}

The experiment was conducted at the Shahjalal Animal Nutrition Field Laboratory, Department of Animal Nutrition, Bangladesh Agricultural University, Mymensingh. The chemical analysis and the in-vitro organic matter digestibility of fodder samples were done in the Animal Nutrition Analytical Laboratory. The climate of the experimental site was characterized by scanty rain and higher temperature during the whole experimental period. The monthly climatological data were recorded. The experimental site was in the old Brahmaputra Flood Plain Agro-ecological zone having non-calcareous dark, gray flood plain. The soil was silt loam texture, neutral in reaction $(\mathrm{pH} 7.0)$ and contained $0.12 \% \mathrm{~N}, 0.07 \%$ $P$ and $1.76 \%$ organic matter.

The experiment was laid out in a Completely Randomized Design (CRD) with three replications in each treatment. There were nine experimental plots each having an area of $36 \mathrm{~m}^{2}$ with a distance of $0.16 \mathrm{~m}$ from plot to plot. The land was prepared by ploughing and cross ploughing four times with bullock-drawn country plough. German, Para and Dhal grass cuttings were collected from the experimental plots of the Department of Animal Nutrition, Bangladesh Agricultural University, Mymensingh. Length of cuttings was $16-18 \mathrm{~cm}$ and contained at least 3 nodes in its sheath. Cuttings of grasses were planted by line sowing

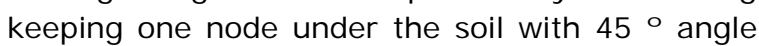
and maintaining a row and plant spacing of $16 \mathrm{~cm}$ with a cutting rate of 16,000 cuttings per hectare. At the time of land preparation 130 t/ha cow dung was applied. After $22 \mathrm{~d}$ of planting, cow dung was applied at the rate of $14.4 \mathrm{t} / \mathrm{ha}$. After $30 \mathrm{~d}$ of first cutting, cow dung was again applied at the rate of $14.4 \mathrm{t} /$ ha with 0.069 ton of urea/ha. Again after $30 \mathrm{~d}$ of $2^{\text {nd }}$ cutting, $14.4 \mathrm{t} /$ ha of cow dung and 0.097 ton of urea/ha were applied. Fertilizer doses were applied in broadcast method. Intercultural operations were done as and when necessary.

\section{Harvesting of fodders}

Fodders were harvested above the ground level $(3-5 \mathrm{~cm})$ after $60 \mathrm{~d}$ of planting. After $60 \mathrm{~d}$ of $1^{\text {st }}$ cutting, the green fodder was harvested again. Then third time green fodder was harvested after $60 \mathrm{~d}$ of $2^{\text {nd }}$ cutting and in every cutting, sample was taken for chemical analysis.

\section{Collection and preparation of samples}

The representative grass samples were collected from each treatment at the time of harvesting. Freshly harvesting plant samples were chopped into small pieces up to $1-2 \mathrm{~cm}$, weighed and sun dried for 2-3 d. After proper sun drying the samples were kept in a drying oven at a temperature of $105^{\circ} \mathrm{C}$ for determination of dry matter. Then the dried samples were ground through 40 mesh sieve. After grinding, the samples were kept into polythene bag, labeled and stored for chemical analysis.

\section{Chemical Analysis}

Samples of each treatment were subjected to chemical analysis for determination of organic matter following the methods of AOAC (2004).

\section{In-vitro organic matter digestibility and Metabolizable Energy}

Approximately two hundred milligrams of air dried sample (Pass to $1 \mathrm{~mm}$ sieve) was weighed into $100 \mathrm{ml}$ calibrated syringes and inoculated with rumen liquor according to Menke et al. (1979). Rumen liquor was collected from rumen cannulated cattle before offering feed and water in the morning and was collected through a cannula with the help of specially made glass fiber probe with a large number of pores drilled in them and covered with fine nylon cloth (pore size generally 50-60 $\mu \mathrm{m}$ ). For representative samples of rumen liquor, probe was placed at five different sites in the rumen. Parallel incubation for measurement of gas production, without feed sample (blank), with $200 \mathrm{mg}$ hay + starch mixture, with $200 \mathrm{mg}$ hay, both as reference standards were also done. Incubations were continued for 24 hours. Gas production was recorded after 24 hours. By using chemical composition and net gas production (corrected for blank and the appropriate reference standards) at $24 \mathrm{hrs}$ incubation (GP, ml), digestibility of organic matter (IVOMD) and metabolizable energy (ME, $\mathrm{MJ} / \mathrm{kg} \mathrm{DM}$ ) were calculated using the following equations proposed by Menke and steingass (1988).

IVOMD $=16.49+0.9042 \mathrm{GP}+0.0492 \mathrm{CP}+0.0387 \mathrm{TA}$

\section{$\mathrm{ME}=2.20+0.1357 \mathrm{GP}+0.0057 \mathrm{CP}+0.000286 \mathrm{EE}$}

where, IVOMD=in-vitro organic matter digestibility (\%); $\mathrm{ME}=$ metabolizable energy (MJ/kg DM); $\mathrm{GP}=$ gas production is expressed in $\mathrm{ml} / 200 \mathrm{mg}$ $\mathrm{DM}$; $\mathrm{CP}=$ crude protein $(\mathrm{g} / \mathrm{kg} \mathrm{DM}) ; \mathrm{TA}=$ total ash ( $\mathrm{g} / \mathrm{kg} \mathrm{DM}) ; \mathrm{EE}=$ ether extract $(\mathrm{g} / \mathrm{kg} \mathrm{DM})$ 


\section{Nutritive value of fodder}

\section{Statistical analysis}

The data were analyzed using the "MSTAT" statistical program in a Completely Randomized Design (CRD), and differences among the treatment means were determined by the Least Significant Difference (LSD) method (Gomez and Gomez, 1984).

\section{Proximate components}

The proximate composition ( $\mathrm{g} / 100 \mathrm{~g}$ DM) of Para, German and Dhal grass cultivated in same level of cow dung and nitrogen fertilizer are presented in Table 1.

\section{Results and Discussion}

\section{Dry matter (DM)}

Dry matter content of Para, German and Dhal grasses are presented in Table 1, 2 and 3 at different stages of maturity. The dry matter content of fodders were highly significant $(p<0.01)$ in the first and second stages of maturity and significant $(p<0.05)$ in the third stage of maturity. The highest DM content was found in German grass in all stages of maturity. This may be due to rapid growth of plants as indicated from the rapid increase in different parts of the forage plant. According to Sen et al. (1978) dry matter ( $\mathrm{g} / 100 \mathrm{~g}$ fresh sample) of Napier grass and Para grass were 30.10 and $40.74 \%$, respectively which are higher than the present study. Jesmin (2009) reported that dry matter content of Para and German were 21.38 \pm 0.40 and $23.14 \pm 0.64 \mathrm{~g} / 100 \mathrm{~g} \mathrm{DM}$, respectively which are nearly close to this study.

Table 1. Chemical composition (g/100 g DM) of three fodders at first cutting

\begin{tabular}{lcccccc}
$\begin{array}{l}\text { Fodders } \\
\text { Name }\end{array}$ & $\begin{array}{c}\text { DM } \\
\text { fresh }\end{array}$ & CP & CF & EE & ASH & NFE \\
\hline Para & $18.4^{\mathrm{c}}$ & 8.9 & 31.5 & 2.10 & $9.4^{\mathrm{b}}$ & 47.9 \\
& \pm 1.1 & \pm 0.8 & \pm 1.8 & \pm 0.4 & \pm 0.3 & \pm 1.9 \\
\hline German & $19.2^{\mathrm{a}}$ & 9.1 & 30.9 & 2.23 & $10.8^{\mathrm{a}}$ & 46.8 \\
& \pm 0.8 & \pm 0.5 & \pm 2.3 & \pm 0.3 & \pm 0.51 & \pm 2.8 \\
\hline Dhal & $18.8^{\mathrm{b}}$ & 8.9 & 30.2 & 2.20 & $10.4^{\mathrm{a}}$ & 48.2 \\
& \pm 1.0 & \pm 0.4 & \pm 1.5 & \pm 0.5 & \pm 0.3 & 1.2 \\
\hline LS & $* *$ & NS & NS & NS & $* *$ & NS \\
\hline
\end{tabular}

Mean values with different superscripts differ significantly; LS, level of significance; NS, non significant; *, $\mathrm{p}<0.05 ; * *, \mathrm{p}<0.01$
Table 2. Chemical composition ( $g / 100 \mathrm{~g}$ DM) of three fodders at second cutting

\begin{tabular}{lllllll}
\hline $\begin{array}{l}\text { Fodders } \\
\text { Name }\end{array}$ & $\begin{array}{l}\text { DM } \\
\text { fresh }\end{array}$ & CP & CF & EE & ASH & NFE \\
\hline Para & $18.9^{\mathrm{b}}$ & 8.1 & 36.0 & 3.01 & 10.3 & $42.5^{\mathrm{b}}$ \\
& \pm 0.8 & \pm 0.5 & \pm 1.6 & \pm 0.7 & \pm 0.1 & \pm 2.3 \\
\hline German & $21.1^{\mathrm{a}}$ & 8.2 & 34.4 & 2.75 & 10.8 & $43.7^{\mathrm{b}}$ \\
& \pm 2.9 & \pm 0.3 & \pm 1.2 & \pm 0.2 & \pm 0.6 & \pm 0.5 \\
\hline Dhal & $19.6^{\mathrm{b}}$ & 7.9 & 34.1 & 2.58 & 10.8 & $44.4^{\mathrm{a}}$ \\
& \pm 1.9 & \pm 0.4 & \pm 1.7 & \pm 0.5 & \pm 0.6 & \pm 2.6 \\
\hline LS & $*$ & NS & NS & NS & NS & $*$ \\
\hline
\end{tabular}

Mean values with different superscripts differ significantly; LS, level of significance; NS, non significant; $*, p<0.05$

Table 3. Chemical composition (g/100 g DM) of three fodders at third cutting

\begin{tabular}{lcccccc}
\hline $\begin{array}{l}\text { Fodder } \\
\text { Name }\end{array}$ & $\begin{array}{c}\text { DM } \\
\text { fresh }\end{array}$ & CP & CF & EE & ASH & NFE \\
\hline Para & $20.0^{\mathrm{c}}$ & 7.8 & $40.9^{\mathrm{a}}$ & 3.6 & 11 & $36.7 \mathrm{~b}$ \\
& \pm 1.2 & \pm 0.4 & \pm 1.6 & \pm 0.8 & \pm 0.4 & \pm 1.5 \\
\hline German & $21.6^{\mathrm{a}}$ & 7.5 & $38.0^{\mathrm{b}}$ & 3.1 & 11.1 & $40.1 \mathrm{a}$ \\
& \pm 1.5 & \pm 0.5 & \pm 0.8 & \pm 0.1 & \pm 0.5 & \pm 1.0 \\
\hline Dhal & $20.5^{\mathrm{b}}$ & 7.6 & $36.1^{\mathrm{c}}$ & 3.8 & 11.3 & $41.2 \mathrm{a}$ \\
& \pm 1.1 & \pm 0.5 & \pm 1.0 & \pm 0.1 & \pm 0.4 & \pm 1.5 \\
\hline LS & $* *$ & NS & $*$ & NS & NS & $* *$ \\
\hline
\end{tabular}

Mean values with different superscripts differ significantly; LS, level of significance; NS, non significant; *, $\mathrm{p}<0.05 ; * *, \mathrm{p}<0.01$

\section{Crude protein (CP)}

The CP content of Para, German and Dhal grass were $8.93 \pm 0.83,9.13 \pm 0.49,8.89 \pm 0.43 \mathrm{~g} / 100 \mathrm{~g}$ DM, 8.12 $\pm 0.54,8.2 \pm 0.33,7.97 \pm 0.42 \mathrm{~g} / 100 \mathrm{~g}$ DM and $7.83 \pm 0.38,7.51 \pm 0.49,7.55 \pm 0.49 \mathrm{~g} / 100$ $g$ DM in the first, second and third cuttings respectively. However, non significant differences in CP content between Para, German and Dhal grass were noted in all stages of maturity. But the highest $\mathrm{CP}$ content was found in German grass compared to the other grasses in first and second stages of maturity. And in third cutting $\mathrm{CP}$ content of all grasses nearly similar to each other. Verma and Singh (1987) reported that significant increase in CP content might be due to rapid synthesis of carbohydrates and their conversion to protein and protoplasm leaving relatively smaller portion for cell wall synthesis. Similar responses were also obtained in different fodder species by Targas and Urrea (1985), Tudsri et al. (1999), Lee et al (2000), Singh et al. (2000) and Johnson et al. (2001). Haque and Stem (1993) reported that $\mathrm{CP}$ content of Para and maize were 10.80 and $7.10 \%$ respectively which are nearly 
similar to those of the present study. The present study also similar to the findings of J esmin (2009) who found that CP content of Para and German grasses were $9.83 \pm 0.67$ and $10.79 \pm 0.85$.

\section{Crude fiber (CF)}

Crude fiber content differs at $5 \%$ level of significance only in the third cutting among the three fodders. Crude fiber (CF) content of Para, German and Dhal grasses were statistically non significant in first and second stages of maturity. Similar results were also obtained by El-Hattab and Harb (1992) in hybrid Sorghum-Sudan grass. The results were also similar with the findings reported by Milked et al. (1994). Significantly $(p<0.05)$ higher CF content of Para grass was found in third cutting. This results were similar with the findings of Jesmin (2009) working with the different non legume fodder where Para grass was found to be higher CF content than German grass.

\section{Ether extracts (EE)}

The values of EE content of Para, German and Dhal grass at different stages of maturity are presented in Table 1. The values of EE content of three treatment grasses were statistically non significant. These values are in agreement with the findings of Jesmin (2009) who worked with Para and German grass and found EE value $2.68 \pm 0.28$ and $2.64 \pm 0.18$. The results were also similar with the earlier investigation by Saha et al. (2001). Ether extract content of Para grass in second cutting $(3.01 \%$ ) is similar to $2.9 \%$ (Sen et al. 1978) and not similar to $2.34 \%$ (Haque and Stem 1993).

\section{Ash}

The average ash contents of Para, German and Dhal grass were 9.40 $\pm 0.25,10.78 \pm 0.51$, $10.43 \pm 0.32 \mathrm{~g} / 100 \mathrm{~g} \mathrm{DM}$ in the first cutting, $10.32 \pm 0.17,10.81 \pm 0.68,10.85 \pm 0.65 \mathrm{~g} / 100 \mathrm{~g}$
$D M$ in the second cutting and $11.01 \pm 0.41$, $11.14 \pm 0.57,11.32 \pm 0.47 \mathrm{~g} / 100 \mathrm{~g} \mathrm{DM}$ in the third cutting respectively. Among all the grasses, German grass showed higher ash content than other grasses. The values of different grasses were significantly $(p<0.01)$ differed in the first cutting only. This result was nearly similar with the findings of Khanum et al. (2007) who found the total ash content of German grass was $13.40 \%$. The result was also similar with Jesmin (2009) who worked with the seven non legume fodder and found significant $(p<0.01)$ difference in total ash content among them. Similar results were also found by Hannan (2004) and Malak (2005) both in German grass and Mondol (2008) in Dhal grass.

\section{Nitrogen free extract}

The values for NFE content of Para, German and Dhal grass were $47.99 \pm 1.9,46.89 \pm 2.89,48.22 \pm$ $1.28 \mathrm{~g} / 100 \mathrm{~g} \mathrm{DM}$ in first cutting, 42.54 \pm 2.32 , $43.77 \pm 0.53,44.49 \pm 2.6 \mathrm{~g} / 100 \mathrm{~g} \mathrm{DM}$ in second cutting and $36.71 \pm 1.54,40.19 \pm 1.07,41.2 \pm 1.51$ $\mathrm{g} / 100 \mathrm{~g} \mathrm{DM}$ in third cutting, respectively. Among the treatment no significant difference was observed in first cutting but in second cutting difference was significant at $5 \%$ level of significance and highly significant $(p<0.01)$ in the third stages of maturity. It was observed from the results that NFE content of these treatments successively decrease with stages of maturity of fodders. However the present findings are nearlysimilar with the research conducted by Malak (2005) who worked with the German grass and found lower NFE content at different stages of maturity. Similar results also observed by Mohiuddin (2002) who worked with oat fodder.

\section{I n vitro organic matter digestibility (I VOMD)}

In-vitro organic matter digestibility (IVOMD) of three fodders is presented in Table 4.

Table: 4. In-vitro organic matter digestibility (IVOMD) and Metabolizable energy (ME) content of three fodders

\begin{tabular}{lcccccc}
\hline Fodders & \multicolumn{3}{c}{ First cutting } & \multicolumn{2}{c}{ Second cutting } & \multicolumn{2}{c}{ Third cutting } \\
\cline { 2 - 7 } Name & IVOMD (\%) & ME (MJ/kg DM) & IVOMD (\%) & ME (MJ/kg DM) & IVOMD (\%) & ME (MJ/kg DM) \\
\hline Para & $57.18 \pm 0.74$ & $7.87 \pm 0.36$ & $58.58 \pm 1.4$ & $8.04 \pm 0.31$ & $58.65 \pm 1.54$ & $8.10 \pm 0.29$ \\
German & $58.35 \pm 1.00$ & $7.98 \pm 0.35$ & $59.97 \pm 2.18$ & $8.18 \pm 0.32$ & $60.00 \pm 2.51$ & $8.16 \pm 0.37$ \\
Dhal & $57.64 \pm 2.20$ & $8.02 \pm 0.08$ & $59.27 \pm 0.90$ & $8.11 \pm 0.15$ & $59.40 \pm 0.61$ & $8.08 \pm 0.06$ \\
Level of sig. & NS & NS & NS & NS & NS & NS \\
\hline
\end{tabular}

IVOMD, in-vitro organic matter digestibility; ME, metabolizable energy; NS, non significant 

It has been observed from Table 4 that there was no significant $(p>0.05)$ difference among the treatments. However, increasing rate of IVOMD showed by all the treatment grasses. Out of three grasses German grass showed higher IVOMD in all stages of maturity. Similar results were also observed by Malak (2005) and Pervin (2004) worked with German grass. Johnson et al. (2001) reported that applying different doses of $\mathrm{N}$ fertilizer on Star grass and Bermuda grass linearly increased in IVOMD of both grasses. In this study, Para grass gave more IVOMD $(57.88 \%)$ in the first stage of maturity than $42.89 \%$ (Khanum et al. 2007) in Pakistan. In this study, IVOMD of Dhal fodder $(57.64 \%)$ is similar to the Napier fodder $57.6 \%$ (Khandaker and Uddin 2002). IVOMD of German fodder (59.97\%) in the second stage of maturity is similar to $59.63 \%$ (Jesmin 2009).

\section{Metabolizable energy}

Metabolizable energy (ME) contents of three fodders are presented in Table 2. There was no significant difference in ME content between Para, German and Dhal grasses. But German fodder showed slightly higher ME content than other treatment grasses. This might be due to the higher response of German grass to the increasing level of nitrogen than other fodders. The present findings is in agreement with the results of Jesmin (2009) who worked with seven non legume fodder and found higher ME content of German grass (7.89 $\mathrm{MJ} / \mathrm{kg} \mathrm{DM}$ ) than Para grass (7.68 MJ/kg DM).

\section{Conclusion}

The result concluded that the quality of three fodders were nearly similar. In respect of nutritive value, German grass showed best result. Therefore, it may be concluded that German, Para and Dhal fodder is suitable for animal production but German fodder is more suitable among the three fodders.

\section{Acknowledgement}

The author is grateful to Bangladesh Agricultural University Research System (BAURES) for funding.

\section{References}

Ali MS, Talukder NM and Karim Z (1987). Effect of fertilizers, trace elements $\left(M_{0}, M n, B\right)$ and sulphur on growth characters and quality of
German grass. Bang. J. Anim. Sci. 16: 3742.

AOAC (2004). Official Methods of Analysis. (16th ed.) Association of Official Analytical chemists, Washington D. C.

BBS (Bangladesh Bureau of Statistics) 2009. Bangladesh Bureau of statistics. Statistical Yearbook of Bangladesh. Statistics Division, Ministry of Planning, Government of the Peoples Republic of Bangladesh.

EL Hattab AH and Harb MY (1992). Effect of planting dates and nitrogen levels on forage yield quality in sorghum Sudan grass hybrid in the central valley. Department of plant production. University of J ordan, P. 11-18.

Gomez KA and Gomez AA (1984). Statistical procedure for Agricultural Research. Int. Rice Res. Inst. John Wiley and Sons. New York, Ckickerster, Brisbane, Toronto, Singapore. P. 139-240.

Hannan MA (2004). Effect on different nitrogen source on yield, chemical composition and nutritive value of Dal grass. MS thesis. Department of Animal Nutrition, Bang. Agri. Univ., Mymensingh.

Haque QME and Stem C (1993). Livestock feeds of Bangladesh: Availability and Nutrient composition. Agricultural Research project II (Supplement) Bang. Agri. Res. Coun./USAID, Dhaka, Bangladesh.

Jesmin F (2009). Nutritional evaluation of seven non-legumes and seven leguminous fodders. MS thesis. Department of Animal Nutrition, Bang. Agri. Univ., Mymensingh.

Johnson CR, Reiling BA, Mislevy $P$ and Hall MB (2001). Effect of nitrogen fertilization and harvest date on yield, digestibility, fibre and protein fractions of tropical grasses. J. Anim. Sci. 79: 2439-2446.

Khan JH and Rinzin (2009). Fodder Germplasm in SAARC Countries. SAARC Agricultural Center. BARC Campus, Farmget, Dhaka1215, Bangladesh.

Khandaker ZH and Uddin MM (2002). Nutritional evaluation of locally available feedstuffs in Bangladesh. Indian Journal of Animal Nutrition. 19: 110-115.

Khanum SA, Yaqoob T, Sadaf S, Hossain M and Sabbar MA (2007). Nutritional evaluation of various feeds stuff for livestock production using in vitro gas method. Pakistan Vet. J. 27: 129-133.

Lee HS and Lee ID (2000). Effect of Nitrogen fertilizer levels on the dry matter yield and 
quality botanical composition in species mixtures. Korean J. Anim. Sci. 42: 727-734.

Malak (2005). Effect different levels of nitrogen and phosphorus on biomass yield, chemical composition and nutritive value of German grass at two stage of maturity. MS thesis. Department of Animal Nutrition, Bang. Agri. Univ., Mymensingh.

Menke KH, Raab L, Salewaski A, Steingass H, Fritz D and Schnerider W (1979). The estimation of digestibility and metabolizable energy content of ruminant feedstuffs from ther gas production when they are incubated with rumen liquor in vitro. J. Agric. Sci. 93: 217-222.

Menke KH and Steingass H (1988). Estimation of energetic feed value obtain from chemical analysis and in vitro gas production using rumen fluid Anim. Res. Dev. 28: 7-55.

Mohiuddin, M. 2002. Response of stage of maturity, different levels of nitrogen and phosphorus fertilizer on yield, Nutritive value and mineral content of oat. MS thesis. Department of Animal Nutrition, Bang. Agri. Univ., Mymensingh.

Mondol MRA (2008). Comparative effect of prilled urea and urea super granules on yield, chemical composition and nutritive value of dal grass. MS thesis. Department of Animal Nutrition, Bang. Agri. Univ., Mymensingh.

Pervin (2004). Effect of different doses of nitrogen and phosphorus fertilizer on yield, chemical composition and nutritive value of German grass. M.S. thesis. Department of Animal Nutrition, Bang. Agri. Univ., Mymensingh, Bangladesh.

Preston TR and Leng RA (1987). Matching ruminant production system with available resources in the tropics and sub-tropics. Panabut Books, Armidale, NSW Australia.

Ranjhan SK and Singh K (1993). Nutrient requirements, feeding standards and feeding of ruminants and their relevance to Indian condition. In: Feeding of ruminants on fibrous crops residues. (Editors, Kiran Singh and J. B. Schere). Indian council of Agricultural Research. Krishi Bhavan, New Delhi, India, P. 117-130.

Razz R, Clavero T, Ferre O, Rivero $Y$ and Amaya A (1996). Energy content of two leucaena leucocephala under different levels of fertilization. Interciencia. 21: 21 -24.

Saha NK, Shahjalal M, Khan MJ and Al-Mamun M (2001). Evaluation of maize and oat forages on the basis of biomass yield, and nutritive value. Progr. Agric. 12: 175-181.

Sen KC, Roy SN and Ranjhan SK (1978). Nutritive value of Indian cattle feeds and the feeding of the animals (6th edition). Indian council of Agril. Res., New Delhi.

Sing D, Singh V and Joshi YP (2000). Effect of nitrogen and cutting intervals on yield and quality of Napier Bajra hybrid. Range management.

Tergas LE and Urrea GA (1985). Effect of fertilization on the yield and nutritive value of tropical forage on an ultisol in Colombia. Tropical Anim. Prods. 10: 68-76

Tudsri S, Bumrung N, Jingnay $Y$, Sayan $T$ and Niran B (1999). Yield and quality of CP of pangola grass under different management technique. III. Effect of split application of nitrogen. Kasersart J. Natural Sci. 33: 303309

Verma SS and Singh V (1987). Quality of forage Oat in relation to nitrogen fertilization. Forage Res. 13: 77. 